\title{
IMPACT OF PERSONAL FACTORS ON TOP PERFORMANCE SKILLS FOR TEAM SPORTS ATHLETES
}

\author{
Evelina Savcheva \\ National Sports Academy "Vassil Levski", Sofia, Bulgaria
}

\begin{abstract}
The aim of the present study is to examine the connections and interrelations among personality traits: extraversion, conscientiousness, agreeableness, emotional stability and openness to experience on mental skills related to successful performance in sport.

The research was done among 77 team sports athletes (13-18 years old), divided into groups according to their age, gender, qualification and sports experience. Our results show a strong influence on personal factors on the level of mental skills associated with successful performance of athletes, which is important for the application in applied sports psychology. There are significant differences depending on gender, age, qualification and sports experience. The relations between the researched indexes were outlined.
\end{abstract}

Key words: personal factors, mental skills, psychological preparation, team sports

\section{INTRODUCTION}

The relations between personality traits and successful athletes are the subject of interest of many Bulgarian and international sports psychologists (Iancheva, 2014; Zhelyazkova-Koynova \& Savcheva, 2005; Domuschieva-Rogleva, Iancheva, \& Varneva, 2014; Iancheva, 2004; Lyubomirova, Fenerova, \& Georgiev, 2008). In order to identify whether personality has any meaningful short-term effects researchers have begun to explore how personality dimensions relate to behaviors associated with success in sport. For instance, a recent study of British gymnasts demonstrated that conscientiousness was positively associated with athletes' quality of preparation in the lead up to competition and emotional stability was positively associated with effective coping during competition (Woodman, et al, 2010). Allen, Frings, \& Hunter (2012) found that athletes with low levels of openness and/or emotional stability are more prone to using avoidance coping strategies, and athletes with high levels of conscientiousness, extraversion, and/or emotional stability are more prone to using problem-focused coping strategies. Król-Zielińska, \& Ciekot-Sołtysiak (2015) examined the basic personality traits of athletes practicing sports disciplines of a different type of physical effort and training (high-speed, endurance and mixed) at a master level and presented the basic structures of behavior associated with the resulting personality profile. The five-factor model of personality could be used to make predictions about the player's performance in sports (Blanco, Hill \& Piedmont, 1999).
The abilities connected with regulating arousal, processing information and managing emotions are crucial determinants of performance for competitive athletes (Thomas et al., 1999). Williams and Krane (2001) suggested that mental strategies were the top components of peak performance. Weinberg and Gould (2011) pointed out that the importance of psychological skills is observable in the favorable attribute of mental toughness which involves the athlete's ability to cope with pressure, control their focus, comeback from failure and face adversity.

The aim of the present study is to examine the connections and interrelations among personality traits: extraversion, conscientiousness, agreeableness, emotional stability and openness to experience on mental skills related to successful performance in sport.

\section{METHOD}

The research was done among 77 team sports athletes (volleyball and basketball; 13 -18 years old), divided into groups according to their age, gender, qualification and sports experience. The empirical information was conduct between March and April 2019.

For the aim of the study the following psychological questionnaires were used:

Test of Performance Strategies (TOPS) - Thomas, Murphy \& Hardy (1999) - Bulgarian adaptation by Zhelyazkova-Koinova, Savcheva, Yordanov (2010). It measures a comprehensive range of psychologi- 
cal skills and techniques, and their strategic use by athletes both in competition and at practice. Subscales were developed targeting eight of the most salient psychological skills and processes thought to underlie successful athletic performance. These skills are goal setting, relaxation, activation, imagery, self-talk, attentional control, emotional control, and automaticity. All of these skills and strategies are measured at practice, but as a result of exploratory factor analyses by Thomas et al., negative thinking rather than attentional control is measured in competition. Respondents are required to assess the frequency of such events on a five-point scale ranging from (1) never, to (5) always.

The other instrument was The Big Five personality test (50-items), (Goldberg, 1992), Bulgarian adaptation by Alexandrova-Karamanova (2016). The dimensions of big five model include extroversion, agreeableness, conscientiousness, neuroticism, and openness to experience (intellect/imagery). Participants were required to indicate, on a 5-point Likert scale (strongly disagree, disagree, neutral, agree, strongly agree), whether the statement was true of them.

The results of the study were processed with the statistical program SPSS 23. We applied comparative analysis, stepwise regression analysis with Varimax rotation and correlation analysis (Spearman criterion).

\section{RESULTS}

The results from the comparative analysis showed statistically significant differences between the researched variables differentiated: by sex (Mann-Whitney) in relation to the following indicators: emotional stability $(U=-3,684 ; \alpha=0,000)$, psychological skills related with competition: goal-settings $(U=-2,588 ; \alpha=0,010)$, emotional control $(\mathrm{U}=-2,865 ; \alpha=0,004)$, activation $(\mathrm{U}=-$ $4,160 ; \alpha=0,000)$, self-talk ( $U=-2,117 ; \alpha=0,034)$, relaxation $(U=-2,851 ; \alpha=0,004)$, negative thinking $(U=-2,065 ; a=0,000)$ as well with psychological skills related with practice: goal-settings $(\mathrm{U}=-3,225 ; \quad \alpha=0,001)$, visualization $(\mathrm{U}=-2,143$; $\alpha=0,032)$, activation $(U=-2,672 ; \alpha=0,008)$ and attention ( $U=-2,447 ; \alpha=0,014)$; by age (Kruskal-Wallis) they were differentiated into three groups (13-
14 years, $15-16$ years and 17-18 years old). There were statistically significant differences in relation to openness to experience $(\chi 2=10,146 ; p=0,006)$ and automaticity, during practices $(\chi 2=8,006$; $\mathrm{p}=0,018)$; by sports experience the results showed only one variation - relaxation during practices $(\chi 2=7,146 ; p=0,028)$. Last, the respondents were divided into two groups (Mann-Whitney) by qualification (medalists and non-medalists) there were discovered statistically significant differences in following variables: visualization $(U=3,833$; $\alpha=0,050)$ and self-talk ( $U=3,896 ; \alpha=0,048)$ during competitions.

Correlation analysis (Figure 1) showed statistically significant correlations between personal factors conscientiousness and agreeableness $(\mathrm{r}=0,014$; $\mathrm{p}=0,280$ ); extraversion and emotional stability $(\mathrm{r}=0,014 ; \mathrm{p}=0,280)$; extraversion and openness to experience $(\mathrm{r}=0,000 ; \mathrm{p}=0,419)$, as well among personal trait and psychological skills (performance strategies) used from athletes in competitions and practices as follow:

- Conscientiousness and mental skills in competitions: automaticity $(\mathrm{r}=0,020 ; \mathrm{p}=-0,264)$; activation $(\mathrm{r}=0,010 ; \mathrm{p}=0,291)$; relaxation $(\mathrm{r}=0,028 ; \mathrm{p}=0,250)$; negative thinking $(\mathrm{r}=$ $0,039 ; \mathrm{p}=-0,236)$ and mental skills in practices: goal-settings $(\mathrm{r}=0,004 ; \mathrm{p}=0,326)$, activation $(\mathrm{r}=0,001 ; \mathrm{p}=0,363)$, attention $(\mathrm{r}=0,000 ; \mathrm{p}=$ $0,453)$.

- Extraversion and activation (in competition) ( $\mathrm{r}$ $=0,000 ; \mathrm{p}=0,415$ ).

- Emotional stability and mental skills in competitions: emotional control $(\mathrm{r}=0,000 ; \mathrm{p}=0,590)$; activation $(\mathrm{r}=0,007 ; \mathrm{p}=0,305)$; relaxation $(\mathrm{r}=$ $0,000 ; \mathrm{p}=0,482)$; negative thinking $(\mathrm{r}=0,000 ; \mathrm{p}$ $=-0,582)$ and mental skills in practices: emotional control $(\mathrm{r}=0,000 ; \mathrm{p}=0,584)$, activation $(\mathrm{r}=$ $0,030 ; \mathrm{p}=0,249)$, attention $(\mathrm{r}=0,021 ; \mathrm{p}=0,264)$.

- Agreeableness and mental skills in competitions: activation ( $\mathrm{r}=0,014 ; \mathrm{p}=0,278)$; self-talk $(\mathrm{r}=0,023$; $\mathrm{p}=0,259)$ and goal-settings (in practices) $(\mathrm{r}=0,031 ; \mathrm{p}=0,246)$.

- Openness to experience and activation (in competitions) $(\mathrm{r}=0,008 ; \mathrm{p}=0,300)$ and mental skills in practices: goal-settings $(\mathrm{r}=0,023 ; \mathrm{p}=0,258)$, automaticity $(\mathrm{r}=0,036 ; \mathrm{p}=0,236)$, self-talk $(\mathrm{r}=$ $0,020 ; \mathrm{p}=0,265)$. 


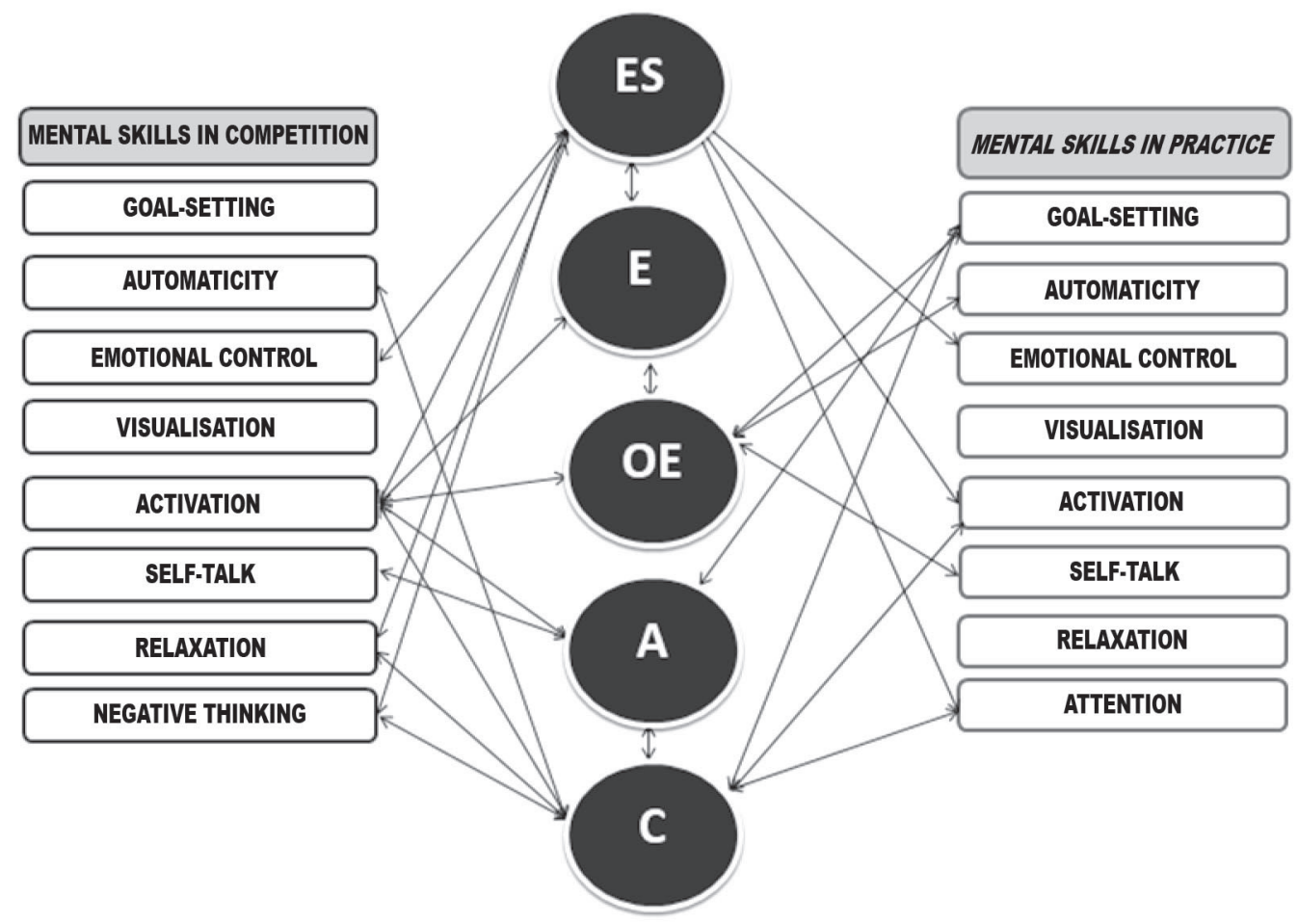

Legend: ES - emotional stability, E - extraversion, OE - openness to experience, A - Agreeableness, C - Conscientiousness

Figure 1. Correlations between personal factors and mental skills

To confirm our results from correlation analysis we've made regression analysis that shows statistically significant dependences as follow:

- extraversion affects activation in competitions (Table 1);

Table 1. Influence of extraversion on mental skills

\begin{tabular}{|c|c|c|c|c|}
\hline \multirow{2}{*}{ Variable } & \multicolumn{5}{c|}{ Extraversion } \\
\cline { 2 - 6 } & $\boldsymbol{\beta}$ & \multicolumn{2}{|c|}{$\mathbf{~ t}$ Sig. } & \multicolumn{1}{|c|}{$\Delta \mathbf{R}^{\mathbf{2}}$} \\
\hline Activation (competitions) &, 291 & 2,926 &, 005 &, 275 \\
\hline
\end{tabular}

- conscientiousness affects goal-settings, automaticity, activation, relaxation (in competitions) and goal-settings, activation, self-talk and attention (in practices). (Table 2);

Table 2. Influence of conscientiousness on mental skills

\begin{tabular}{|c|c|c|c|c|}
\hline \multirow{2}{*}{ Variable } & \multicolumn{4}{|c|}{ Conscientiousness } \\
\hline & $\beta$ & $\mathbf{t}$ & Sig. & $\Delta \mathrm{R}^{2}$ \\
\hline Goal-settings (competition) & ,274 & 2,466 & ,016 & $\mid$\begin{tabular}{|l|} 
\\
\end{tabular} \\
\hline Automaticity (competition) &,- 253 & $-2,265$ & 026 & ,064 \\
\hline Activation (competition) & ,461 & 4,642 & 000 &, 191 \\
\hline Relaxation (competition) & 211 & 2,147 &, 035 & ,294 \\
\hline Goal-settings (practices) & ,354 & 3,379 & 001 &, 135 \\
\hline Activation (practices) & ,383 & 3,721 & 000 &, 162 \\
\hline Self-talk (practices) & ,218 & 2,005 & 049 &, 132 \\
\hline Attention (practices) & ,493 & 5,054 &, 000 & 262 \\
\hline
\end{tabular}


- emotional stability affects emotional control, negative thinking, relaxation (in competitions) and activation and attention (in practices) (Table 3);

Table 3. Influence of emotional stability on mental skills

\begin{tabular}{|l|c|c|c|c|}
\hline \multirow{2}{*}{\multicolumn{1}{|c|}{ Variable }} & \multicolumn{4}{c|}{ Emotional stability } \\
\cline { 2 - 5 } & $\boldsymbol{\beta}$ & $\mathbf{t}$ & $\mathbf{S i g}$ & $\boldsymbol{\Delta} \mathbf{R}^{\mathbf{2}}$ \\
\hline $\begin{array}{l}\text { Emotional control } \\
\text { (competition) }\end{array}$ &, 583 & 6,209 &, 000 &, 339 \\
\hline $\begin{array}{l}\text { Negative thinking } \\
\text { (competition) }\end{array}$ & $-5,888$ &, 000 &, 316 & $-5,888$ \\
\hline Relaxation (competition) &, 481 & 4,899 &, 000 &, 250 \\
\hline Activation (practices) &, 266 & 2,583 &, 000 &, 232 \\
\hline Attention (practices) &, 197 & 2,021 &, 047 &, 300 \\
\hline
\end{tabular}

- agreeableness affects self-talk (in competitions). (Table 4);

Table 4. Influence of agreeableness on mental skills

\begin{tabular}{|l|c|c|c|c|}
\hline \multirow{2}{*}{ Variable } & \multicolumn{5}{|c|}{ Agreeableness } \\
\cline { 2 - 6 } & \multicolumn{2}{|c|}{$\boldsymbol{\beta}$} & $\mathbf{t}$ & \multicolumn{2}{c|}{ Sig. } & \multicolumn{1}{c|}{$\Delta \mathbf{R}^{\mathbf{2}}$} \\
\hline Self-talk (competitions) &, 265 & 2,379 &, 020 &, 070 \\
\hline
\end{tabular}

- openness to experience affects goal-settings, visualization (in practices). (Table 5).

Table 5. Influence of openness to experience on mental skills

\begin{tabular}{|c|c|c|c|c|}
\hline \multirow{2}{*}{ Variable } & \multicolumn{4}{|c|}{ Openness to experience } \\
\hline & $\beta$ & $\mathbf{t}$ & Sig. & $\Delta \mathrm{R}^{2}$ \\
\hline Goal-settings (practices) & ,237 & 2,265 &, 026 & ,191 \\
\hline Visualization (practices) & 257 & 2,307 & 024 & 066 \\
\hline
\end{tabular}

\section{DISCUSSION}

According to gender differences we found that male athletes are more likely to set goals in competitions, better control their emotions, are more effective in managing activation, internal dialogue and negative thinking in the race. They are also more likely to use relaxation techniques in training than female athletes. In terms of mental skills related to training - men are more focused, use more visualization as a cognitive technique, to prepare themselves in training, manage their attention and activation more effectively for upcoming workout loads compared with the women in the sample.

The differences that we found according to the age distribution of the athletes showed that openness to experience, increased progressively with the age. This implies that with age, younger athletes become more curious, have broad interests, expand creative thinking, strive for originality, actively develop their imagination. Considering of the changes that occur during adolescence and according to the age periodization of mental development, our results confirm the results reported in the literature.

Medalists do not differ from those outside the top three in terms of personality factors (extraversion, agreeableness, consciousness, openness to experience, emotional stability), but statistically significant differences in performance-related mental skills (performance strategies) are found. Non-medalists have higher values of mental skills self-talk and visualization during competitions. This result contradicts with the findings of research in sports, related to these indicators since their low level is characteristic of lower skilled athletes and vice versa. 
Athletes with more experience apply relaxation more often in training than beginners.

Our results show a strong influence of personality factors on the level of mental skills associated with successful performance of athletes. The most important to the practice are the results of the regression analysis, which showed that all the basic personality factors included in The Big Five personality test affect almost all the mental skills associated with both competitions and trainings. Those athletes who are more organized, persistent and motivated (have higher levels of "consciousness ") will more often set goals, more effectively control their activity level in practices and competitions, more often apply relaxation techniques during competitions and during trainings, more effectively will manage the words they say to themselves as well as the focus of their attention. Extraversion measures the breadth and intensity of interpersonal interactions, the level of activity, the need for external stimulation, etc., our research has shown that high sociability, an orientation toward human interaction, optimism and activity, influence the ability to activate by competitions and vice versa. This confirms the results of many studies on extraversion as a personality trait, which define the extrovert as able to recover quickly from stress, be more optimistic, avoid negative thoughts, seek an active solution to dealing with various difficulties, interacting with others or seeking more informa-

\section{REFERENCES}

Aleksandrova-Karamanova, A. (2016). Markeri na Golemite pet faktora. Mezhdunaroden lichnostov aytem fond - L. Goldberg. Rakovodstvo za ipolzvane balgarskata versia na vaprosnika. Nepublikuvan rakopis. // Александрова-Караманова, А. (2016). Маркери на Големите пет фактора. Международен личностов айтем фонд - Л. Голдбърг. Ръководство за иползване българската версия на въпросника. Непубликуван ръкопис.

Allen, M. S., Frings, D., \& Hunter, S. (2012). Personality, coping, and challenge and threat states in athletes. International Journal of Sport and Exercise Psychology.

Domuschieva-Rogleva, G., Yancheva, M. and Varneva, M. (2014). Lichnostni determinanti na nivoto na samokontrol pri sastezateli po sambo. In: Personality, motivation, sport. Vol. 19, NSA PRES, Sofia, pp. 21-31.// Личностни детерминанти на нивото на самоконтрол при състезатели по самбо.

Goldberg, L. R. (1992). The development of markers for tion from external sources. The personal factor agreeableness concerns how well people get along with others. People high in agreeableness tend to be well-liked, respected, and sensitive to the needs of others. Our results showed that this personality trait influences internal dialogue during competitions. The higher the scores on this indicator, the more athletes would use effective cognitive techniques to regulate their thoughts and psychological states during competitions. Openness to experience concerns people's willingness to try to new things, their ability to be vulnerable, and their capability to think outside the box. It is also sometimes called intellect or imagination. Athletes who are curious and have more imagination and creative thinking will apply more visualization and set goals in training and vice versa. Those athletes who have less analytical and creative thinking would be less likely to apply the mental skills that are associated with successful performance.

In order to find possible differences between different kind of sports (not only team sports) we have to examine a greater number of athletes.

In conclusion, the results of the study supported our hypothesis that underlying personality factors in which many related traits and characteristics fit, influence the level of mental skills that are associated with athlete's performance and implemented as performance strategies.

the Big-Five factor structure. Psychological Assessment, 4(1), pp.26-42.

Hurtz, G. M., \& Donovan, J. J. (2000). Personality and job performance: The big five revisited. Journal of Applied Psychology, 85(6), pp.869-879.

Iancheva, T. (2004). Lichnost i sastezatelna realizatsia, NSA PRES, Sofia. // Янчева, Т. (2004). Личност и състезателна реализачия. НСА Прес, София.

Król-Zielińska, Magdalena \& Ciekot, Monika \& Zieliński, Jacek \& Kusy, Krzysztof. (2015). The personality of highly trained athletes in view of the Big Five model. Antropomotoryka. Journal of Kinesiology and Exercise Sciences. 72. 29-34. 10.5604/17310652.1210187.

Lyubomirova, S., Fenerova, D. and Georgiev, M. (2008). Vliyanie na tipologichnite osobenosti varhu predsastezatelnata trevozhnost pri sportisti po tenis. In: Personality, motivation, sport. Book 2, Vol. 13, NSA PRES, Sofia, pp. 24-32. (In Bulgarian: Влияние на типологичните особености върху предсъстезателната тревожност 
при спортисти по тенис.)

Peeters, M. A. G., Van Tuijl, H. F. J. M., Rutte, C. G., \& Reymen, I. M. M. J. (2006). Personality and team performance: A meta-analysis. European Journal of Personality, 20, pp.377-396.

Piedmont, R., Hill, D., Blanco, S. (1999). Personality and Individual Differences, 27, 4; pp.769-777.

Thomas, P., Murphy, S. \& Hardy, L. (1999). Test of performance strategies: Development and preliminary validation of a comprehensive measure of athletes' psychological skills, Journal of Sports Sciences, 17:9, 697-711, DOI: 10.1080/026404199365560. Yancheva, M. (2015). Psihologicheski faktori na sportnite postizhenia pri sastezateli po sambo, Dissertation. National Sports Academy, Sofia // Янчева, М. (2015). Психологически фактори на спортните постижения при състезатели по самбо. Национала спортна акдемия, София.

Weinberg, R. S., Gould, D. (2011). Foundations of sport and exercise psychology. Champaign, IL: Human Kinetics.

Williams, J.M. and Krane, V. (2001). Psychological Characteristics of Peak Performance. In: Williams, J.M., Ed., Applied Sport Psychology: Personal Growth to Peak Performance, May Field Publishing Company, Mountain View, pp.137-144.

Woodman, T., Zourbanos, N., Hardy, L., Beattie, S., \& McQuillan, A. (2010). Do performance strategies moderate the relationship between personality and training behaviors? An exploratory study. Journal of Applied
Sport Psychology, 22, pp.183-197.

Zhelyazkova-Koinova, Z., Savcheva, E. (2005). Model na vzaimodeystvieto mezhdu lichnostnite osobenosti, faktorite na sastezatelnata sreda i sastezatelnata realizatsia pri fehtovachi (14-19 g.) Personality, motivation, sport. Vol. 10, NSA PRES, Sofia, pp. 77-82. // Желязкова - Койнова, Ж., Савчева, Е. (2005). Модел на взаимодействието между личностните особености, факторите на състезателната среда и състезателната реализация при фехтовачи (14-19 г.). В: Личност, мотивация, спорт, Т. 10, НСА ПРЕС, София, стр. 77-82.

Zhelyazkova-Koynova, Z., Savcheva, E., Yordanov, V. (2010). Balgarska adaptatsia na testa za izsledvane na strategii za postizhenie (TOPS). In: Personality, motivation, sport, Vol. 15. NSA Pres, Sofia, pp. 105-115. ISBN 978-954-718-279-0). // Желязкова - Койнова, Ж., Савчева, Е., Йорданов, В. (2010). Българска адаптация на теста за изследване на стратегиите за постижение (TOPS). В: Личност, мотивация, спорт, Т. 15, НСА ПРЕС стр. 105-115.

Corresponding author: Evelina Savcheva, PhD

Chief Assistant National Sports Academy "Vassil Levski", 21, Akad. Stefan Mladenov str. Sofia 1700, Bulgaria E-mail: esavcheva@gmail.com 